as a new species. Not mentioned by Macoun $(1892,1902)$ and it may be a synonym of $G$. anodon or $G$. plagiopodia.

G. plagiopodia Hedw.

On sandstone, SCHPP East Block, June 24, 1894.

Hypnum cupressiforme Hedw.

On earth, SCHPP East or Centre Block, August 4, 1880.

H. revolutum (Mitt.) Lindb.

Cypress Hills. No specimen seen at the National Museum but reported by Macoun (1892).

H. vaucheri Lesq. (as H. subcomplexum n. sp.)

Sandstone rocks, Cypress Hills, Saskatchewan. No specimen seen at the National Museum but reported by Kindberg (1896-97) who described it as $H$. subcomplexum, and mentioned by Macoun (1902).

Leptodictyum riparium (Hedw.)

Warnst. (as $H$. riparium)

By pools, SCHPP East Block, June 25, 1894.

In water, SCHPP East Block, June 26, 1894.

Philonotis fontana var. pumila Brid. (as $P$. fontana)

By springs, SCHPP East Block, June 25, 1894.

Plagiomnium cuspidatum (Hedw.)

Kop. (as Mnium drummondii)

On the base of trees, SCHPP East Block, June 26, 1894.

P. rugicum (Laur.) Kop. (as Mnium affine)

Around springs, SCHPP East Block, June 23, 1894.

Pottia heimii (Hedw.) Fürnr.

ex Hampe
On earth, Fairwell Creek, Saskatchewan, June 27, 1895.

Pseudoleskeela tectorum (Funck ex Brid.) Kindb. ex Broth. (as Amblystegium adnatum)

On sandstane rocks, SCHPP East Block, June 24, 1894.

Tortula mucronifolia Schwaegr. (as Barbula mucronifolia)

Bank of Fairwell Creek, Saskatchewan, June 27, 1895.

T. ruralis (Hedw.) Gaertn., Meyer \& Scherb. (as Barbula ruralis)

SCHPP East or Centre Block, August 2,1880 .

On rocks, SCHPP East or Centre Block, August 3, 1880.

\section{Summary}

The itineraries of John Macoun's collecting trips to the Cypress Hills have been described and the species of bryophytes and lichens which he collected have been listed along with their dates and probable places of collection. It has been shown that contrary to various reports, all of his collections of these plants were made on the Saskatchewan side of the Hills.

\section{Literature Cited}

Cardot, J. and I. Theriot. 1904. New or unrecorded mosses of North America. 2. Bot. Gazette, $37: 363-382$.

Kindberg, N. C. 1896-1897. Species of European and North American Bryineae. Linkoeping, Sweden.

Macoun, J. 1882. Manitoba and the great North West. Guelph.

Macoun, J. 1892. Catalogue of Canadian Plants. VI. Musci. Montreal.

Macoun, J. 1902. Catalogue of Canadian Plants. VII. Lichens and Hepaticae. Ottawa.

Macoun, J. 1922. Autobiography of John Macoun, M.A. Ottawa Field-Naturalists' Club, Ottawa.

Welch, W. H. 1960. A monograph of the Fontinalaceae. Nijhoff, The Hague.

\title{
NOTES ON THE BRYOPHYTE FLORA OF THE CYPRESS HILLS
}

by C. D. Bird, Deparmtent of Biology, University of Calgary

In $1962 \mathrm{I}$ published a paper on the oryophytes of the Cypress Hills Provincial Parks of Alberta and Saskatchewan (Bird, 1962). Since that time a number of additional collections, including some new records, have been made in the area by J. S. Rowe and by $R$. D. Newsome who published a detailed account of the vegetation of the area (Newsome and Dix, 1968). Recent taxonomic changes and the revision of some material have resulted 


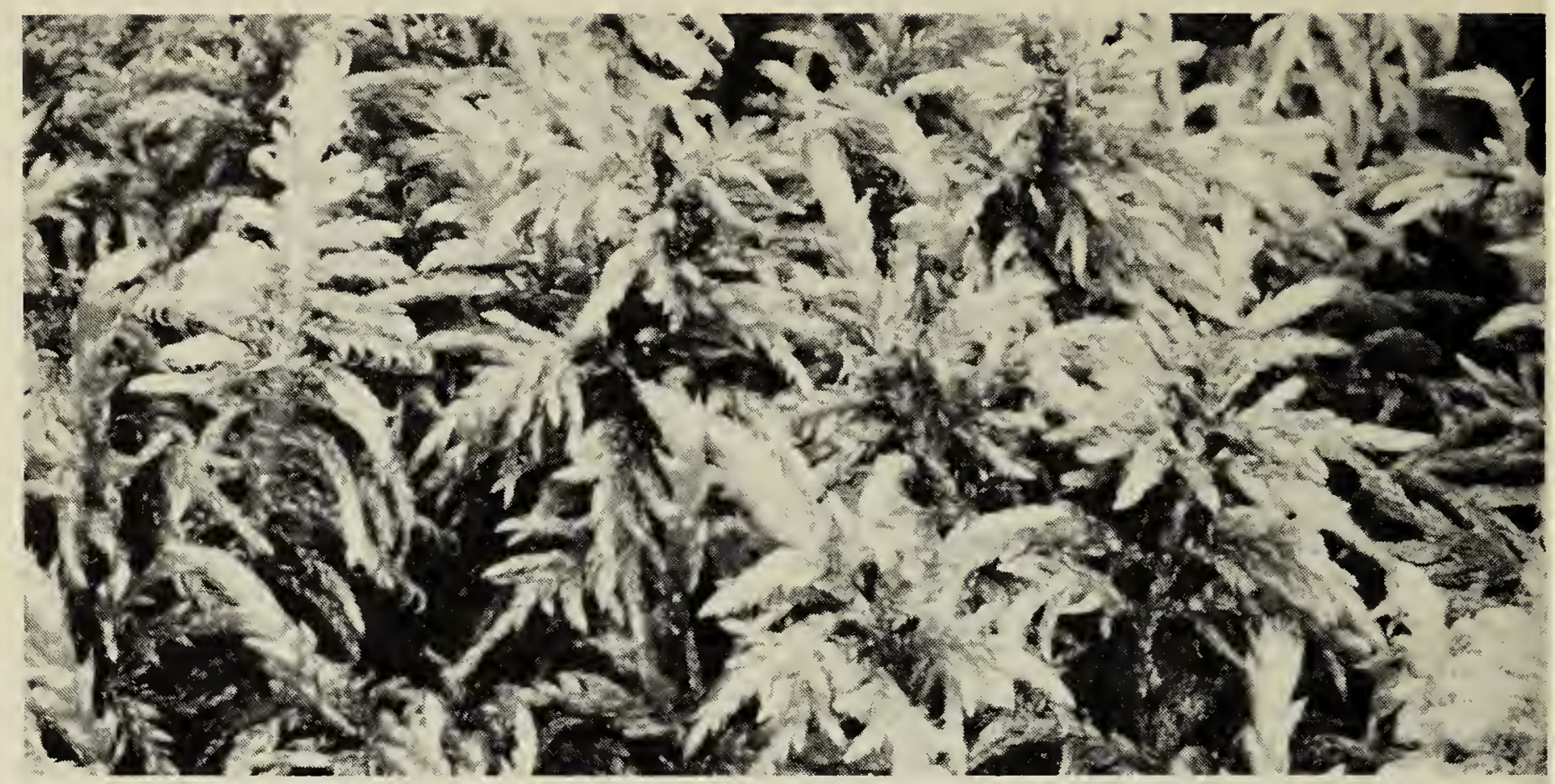

Hylocomium splendens, one of the feather mosses common in the lodgepole pine woods in the Cypress Hills. (C. D. Bird \#2212. Centre Block. August 3, 1960.)

in a number of currections, new names, and additions which are worthy of note.

The following list contains all of the new records or changes which have come to my attention. Voucher specimens have been deposited in the Herbarium of the Department of Biology, University of Calgary.

\section{Liverworts}

Chiloscyphus polyanthus (L.) Corda

Saskatchewan: Centre Block, small valley running west from Loch Leven, Windfall Spruce Nature Trail, in wet hollows among white spruce roots, J. S. Rowe 1256. New to the Cypress Hills.

\section{Lophocolea heterophylla (Schrad.) Dum.}

Saskatchewan: West Block, mixed white spruce-aspen woods, northfacing slope, on log with Tetraphis pellucida, R. D. Newsome 61-61. New to the Saskatchewan side of the Cypress Hills.

\section{Ricciocarpus natans (L.) Corda}

Saskatchewan: Centre Block, 17-826-W3, floating on the surface of beaver ponds with Lemma minor L. and on the muddy edge of the ponds, R. D. Newsome 1-64. New to the Cypress Hills.

\section{Mosses}

Atrichum undulatum (Hedw.)

P. Beauv.

This species must be removed from the flora of the Cypress Hills as, in the light of new information (Ireland, 1969), plants previously determined as this are actually $A$. selwynii Aust.

Brachythecium glareosum (Spruc.) B.S.G.

In his generic revision of North American Brachytheciaceae, Robinson (1962) indicated that he examined no North American specimens of this species and that it has been confused with the $B$. salebrosum group. The material which I had cited as this in my earlier paper was found to be $B$. salebrosum, a common species in the area.

\section{Campylium polygamum (B.S.G.)}

C. Jens.

Saskatchewan: Centre Block, small valley running west from Loch Leven, Windfall Spruce Nature Trail, on moist decayed wood under white spruce, with Chiloscyphus pallescens, J. S. Rowe 1259. New to the Saskatchewan side of the Cypress Hills.

Eurhynchium diversifolium ('Schleich) B.S.G.

The recent check list of North American mosses (Crum, Steere and Anderson 1965) places this as a syn- 


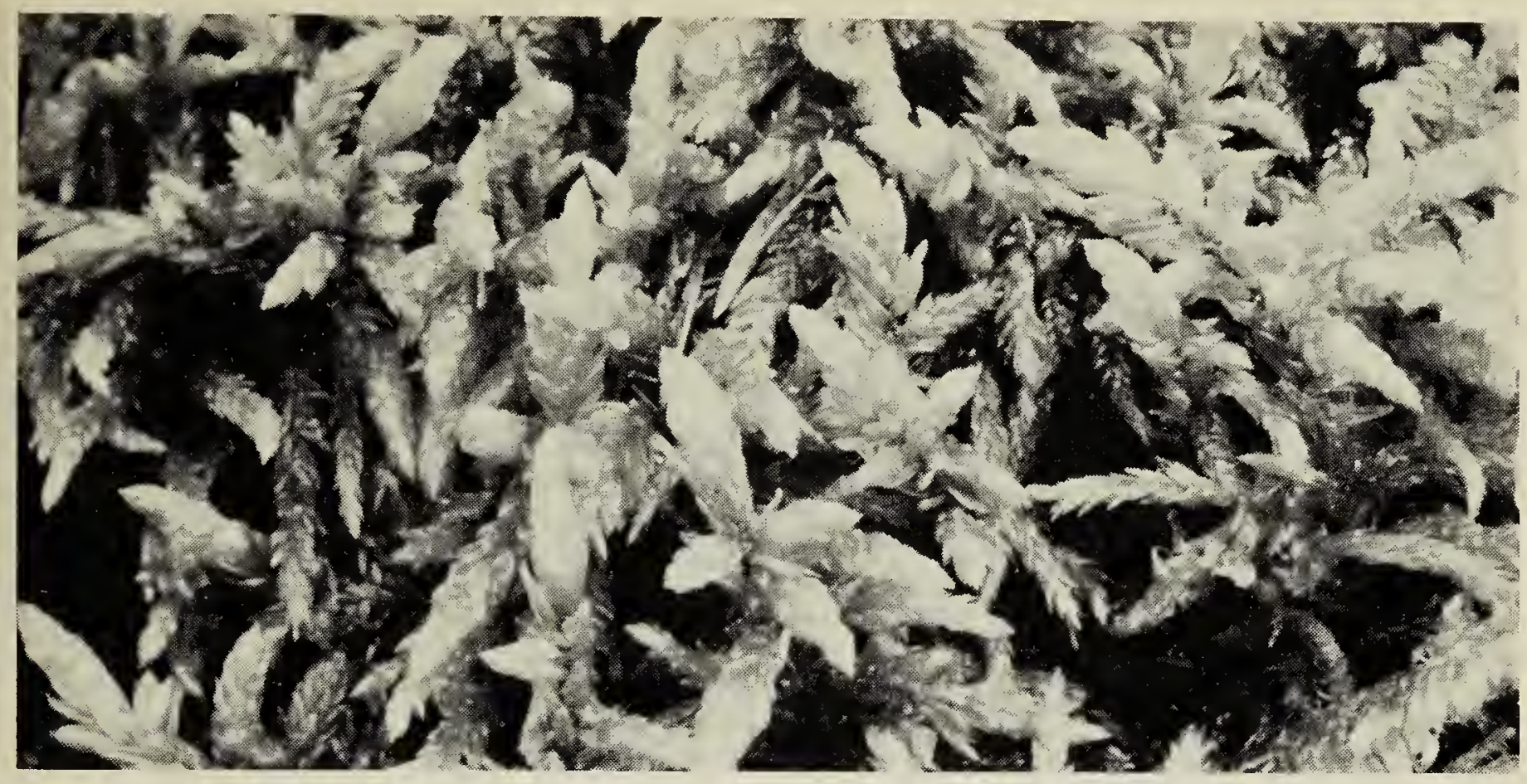

Pleurozium schreberi, a feather moss common in lodgepole pine woods in Cypress Hills Centre Block. (C. D. Bird \# 2213, August 3, 1960.)

onym of $E$. pulchellum (Hedw.) Jenn., a species already reported from the Cypress Hills.

Homomallium adnatum (Hedw.)

Broth.

The Macoun report of this species mentioned in my earlier paper was based on a voucher (Canadian Cryptogams No. 13) in the National Museum of Canada. It was examined recently and was found to be Pseudoleskeela tectorum (Funck ex Brid.) Kindb. ex Broth. Homomallium adnatum must therefore be deleted from the bryoflora of the Cypress Hills and Pseudoleskeela tectorum must be added. Data on the packet indicates it was collected by John Macoun on sandstone rocks, Cypress Hills, Assiniboia, on June 24, 1894.

Hygrohypnum luridum (Hedw.) Jenn.

Alberta: near Elkwater, 13-8-3-W4, white spruce - lodgepole pine woods, on $\log$ in a creek, R. D. Newsome 40-61. New to the Cypress Hills.

\section{Mnium.}

The recent generic revision of the genus Mnium by T. Koponen (1968) has resulted in a number of new names for Cypress Hills species: Mnium affine var. rugicum is now Plagiomnium rugicum (Laur.) Kop., Mnium cuspidatum is Plagiomnium cuspi- datum (Hedw.) Kop., Mnium drummondii is Plagiomnium drummondii (Bruch \& Schimp.) Kop., Mnium medium is Plagiomnium medium (B.S.G.) Kop., and Mnium punctatum is Rhizomnium punctatum (Hedw.) Kop. Dr. Kopenen has examined much of my material and has made two corrections which are mentioned later.

Mnium marginatum (With.) Brid. ex P. Beauv.

Saskatchewan: Centre Block, small valley running west from Loch Leven, Windfall Spruce Nature Trail, on exposed mineral soil in forest openings, J. S. Rowe 1249. New to the Saskatchewan side of the Cypress Hills.

Philonotis fontana (Hedw.) Brid.

Saskatchewan: Centre Block, 19-8. 26-W3, boggy white spruce woods, on mineral soil, R. D. Newsome 2-62; West Block, white spruce - lodgepole pine - aspen woods, north-facing slope, on wet $\log$, R. D. Newsome 3-63. New to the Saskatchewan side of the $\mathrm{Cy}$ press Hills.

Plagiomnium ciliare (C. Müll.) Kop.

Saskatchewan: Centre Block, south of Lonepine Campsite, lodgepole pine woods, on rotten $\operatorname{logs}$, C. D. Bird 4743. New to the Cypress Hills.

Plagiomnium medium (B.S.G.) Kop.

The record of Bird 4775 from the 


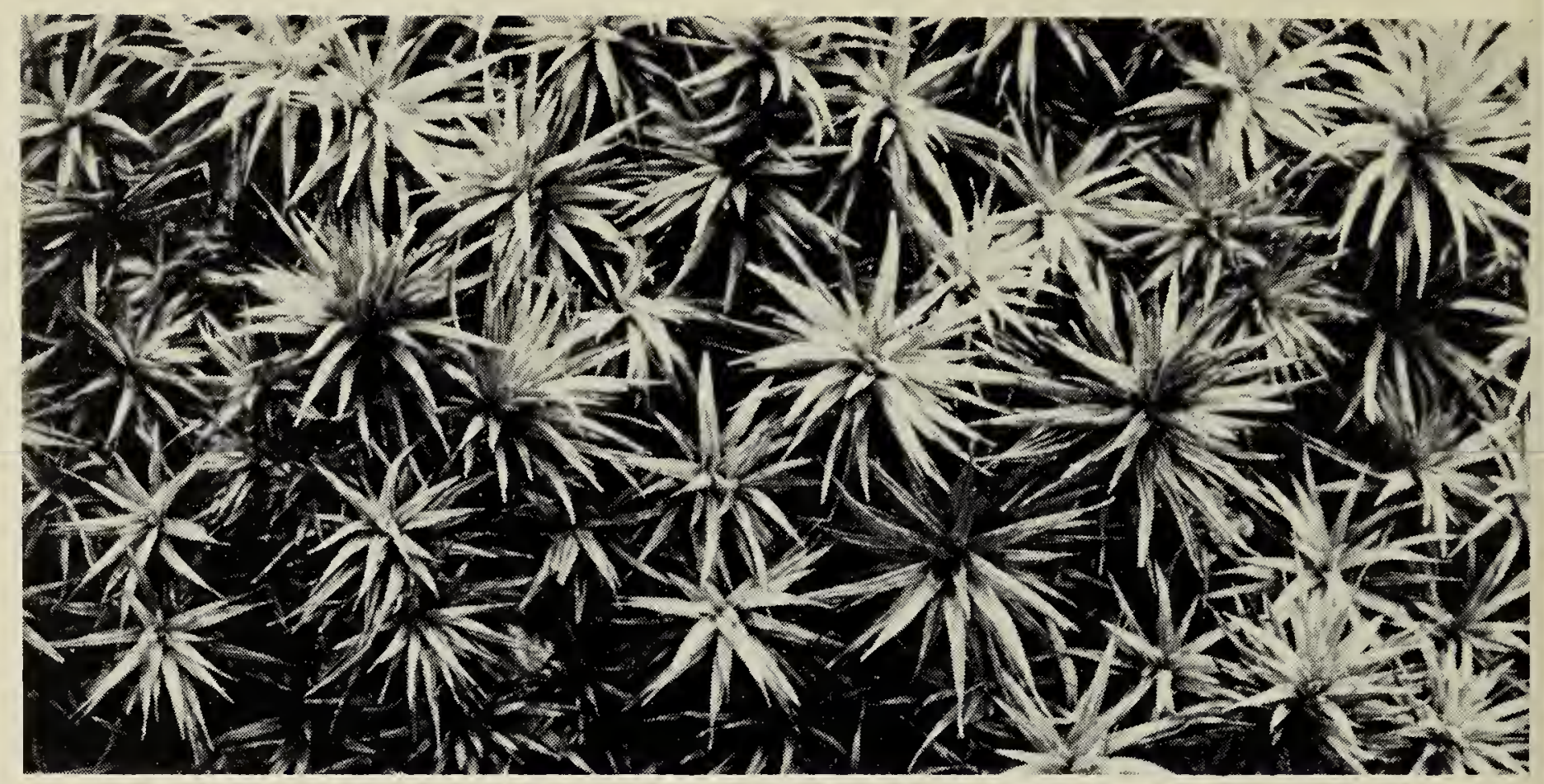

Polytrichum juniperinum, hair cap moss, common throughout the Cypress Hills. (C. D. Bird \# 2214. August 3, 1960.)

Saskatchewan side is in error as the plant was actually $P$. rugicum. The species is fairly common there, however, on wet soil beside streams and seepage areas. The following collections document its presence: C. D. Bird $4738,4798,4824,4839,4850$ and R. D. Newsome 15-61.

Alberta: one-half mile west of Elkwater, white spruce woods, northfacing hillside, C. D. Bird 4407. New to the Alberta side of the Cypress Hills.

Plagiomnium rugicum (Laur.) Kop.

The record of Bird 4798 from the Saskatchewan side is in error as the plant was actually $P$. medium. It is quite common on both sides, however, in the same habitats as the previous species. The following collections document its presence on the Saskatchewan side: Bird 4692, 4695, 4775, 4780, 4831, and J. S. Rowe 1244.

\section{Discussion and Summary}

Five species, Chiloscyphus polyanthus, Ricciocarpus natans, Hygrohypnum luridum, Plagiomnium ciliare, and Pseudoleskeela tectorum, have been added while four species, Atrichum undulatum, Brachythecium glar. eosum, Eurhynchium diversifolium, and Homomallium adnatum, have been deleted from the bryoflora of the $\mathrm{Cy}$ press Hills. The revised totals now become 99 mosses and 9 liverworts. None of the additional plants are montane, hence the montane distributional element, represented by nine species, drops to $8.3 \%$ from $9.1 \%$ as given in Bird (1962). This is strikingly similar to the $8.6 \%$ present in the vascular plants (de Vries and Bird, 1968) and indicates that the two groups have similar distributional patterns.

Four species, Lophocolea heterophylla, Campylium polygamum, Mnium marginatum, and Philonotis fontana, have been added to the flora of the Saskatchewan side of the Hills, while one species, Plagiomnium medium, has been added to that of the Alberta side.

\section{LITERATURE CITED}

Bird, C. D. 1962. Bryophytes of the Cypress Hills Provincial Parks, Alberta and Saskatchewan. Can. J. Botany, 40:573-587.

Crum, H., W. C. Steere, and L. E. Anderson. 1965. A list of the mosses of North America. Bryologist, $68: 377-432$.

Ireland, R. R. 1969. Taxonomic studies on the genus Atrichum in North America. Can. J. Botany, $47: 353-368$.

Koponen, T. 1968. Generic revision of Mniaceae Mitt. (Bryophyta). Annales Botanici Fennici, $5: 117-151$.

Newsome, R. D., and R. L. Dix. 1968. The forests of the Cypress Hills, Alberta and Saskatchewan, Canada. Amer. Midland Nat., $80: 118-185$.

Robinson, H. 1962. Generic revisions of North American Brachytheciaceae. Bryologist, 65 : 73-146.

deVries, B., and C. D. Bird. 1968. Additions to the vascular flora of the Cypress Hills, Alberta. Blue Jay, 26:98-100. 